\title{
PEREIRA, Sônia Maria de Souza. Bullying e suas implicações no ambiente escolar. São Paulo: Paulos, 2009. 96p.
}

O cinema, nos últimos anos, tem nos apresentado uma série de filmes que abordam a violência nas escolas. Basta assistir aos filmes: Visitor Q(Japão/2001), Tiros em columbine (EUA/2002), Elefante (EUA/2003), Escola da violência (Coreia do Sul/2006), É só uma questão de tempo (Austrália/2006), Klass (Estônia/2007), A onda (Alemanha/2008), Entre os muros da escola (França/2009) Embora nem todos os filmes sejam baseados em fatos reais, eles demonstram que o problema da violência nas escolas é comum ao conjunto das sociedades.

No Brasil, como sabemos, não é diferente; professores convivem com cenas reais de brigas entre alunos que envolvem agressões físicas com socos, chutes ou agressões psicológicas, por meio de ofensas, difamações (inclusive dirigidas aos próprios professores); e ainda grupos de alunos ou ex-alunos depredando o patrimônio, munidos de armas ou drogas, comprometendo a integridade da vida escolar.

As formas de violência no ambiente escolar são variadas e envolvem uma mutiplicidade de atos. O mesmo ocorre com os fatores determinantes para sua ocorrência, pois abarcam desde questões psicológicas, familiares, socioeconômicas, e também circunstânciais como o uso de drogas lícitas ou ilícitas.

No contexto das diferentes formas de manifestações da violência na escola, temos ainda o bullying, termo de origem inglesa, derivado do adjetivo bully, que significa valentão, tirano; um tipo de violência entre os alunos, caracterizada pela ocorrência de agressões de ordem física e/ou psicológica, geralmente por um longo período e de forma repetitiva, na qual se evidencia um desequilíbrio de poder entre agressor e vítima.

O bullying é um problema que vem sendo detectado como em muitas escolas, sejam públicas ou privadas. Mesmo assim, profissionais da educação desconhecem suas características, ou as graves consequências dos atos cruéis e intimidadores. Por conta desse desconhecimento, ele é confundido com a indisciplina ou brincadeiras entre alunos ou grupos de alunos, por vezes de cará-

\section{Telma Brito Rocha}

Doutoranda em Educacão pela Universidade Federal da Bahia (UFBA).

telmabr@hotmail.com 
ter físico, que envolvem contato pessoal, discussões ou brigas corriqueiras, ocasionais, em pares de igual força e poder.

Nesse sentido, o livro Bullying e suas implicações no ambiente escolar, fruto de uma monografia defendida no curso de Pedagogia da UFBA em 2007, sob a orientação da professora Celma Borges, é uma obra importante, pois ajuda pais e profissionais da educação no entendimento dessa temática. Por meio de uma revisão bibliográfica, a autora analisa porque é tão difícil para as escolas detectarem o bullying, quais as consequências para o desenvolvimento cognitivo e afetivo dos alunos vitimados; como as escolas e as famílias podem prevenir e combater o bullying.

O livro é composto de pequenos capítulos, seis ao todo, incluíndo a conclusão. De maneira clara e objetiva, a autora apresenta na introdução a estrutura do livro, pontuando que seu trabalho não tem pretensão de apresentar soluções definitivas, mas desenvolver algumas reflexões sobre a gravidade do problema, e também medidas para o seu enfretamento no ambiente escolar.

No capítulo dois, a autora revisa os conceitos de violência e seus possíveis condicionantes como fator explicativo desse fenômeno. Considera que o conceito varia em diferentes períodos da história da humanidade, ou seja, depende da forma como cada indivíduo compreende o tema, a partir de seus valores e sua ética. Assim, o termo é complexo e polissêmico, visto que é usado para designar fenômenos variados e distintos. Dentre os fatores determinantes para a violência, entre os mais citados em sua revisão bibliográfica está a desestruturação familiar, e o alto índice de exclusão social.

No capítulo três, parte do histórico para explicar o conceito de bullying, e as diferenças entre bullying e indisciplina. Essa discussão que a autora traz é importante, porque sabemos que, embora os estudos sobre a questão da violência na escola já aconteciam desde os anos 70, na Suécia, Reino Unido, Estados Unidos da América (EUA), só nos anos 80 é que Dan Olweus, pesquisador da Universidade de Bergen na Noruega, desenvolveu os primeiros critérios para detectar o problema de forma específica, e assim diferenciá-lo de outras possíveis interpretações, que envolviam indisciplina e brincadeiras entre alunos - as chamadas gozações. Já no Brasil, até 2003, o termo não era mencionado nas pesquisas sobre violência escolar, somente em 2005, conforme a autora, os estudos de Lopes Neto (2005), Fante (2005), 
Seixas (2005) e Murriel e outros autores. (2006) discutem a questão (p. 36).

Segundo Pereira, o bullying se manifesta através de insultos, intimidações, apelidos cruéis, gozações que magoam profundamente, acusações injustas, tomar pertences, meter medo, atuação de grupos que hostilizam, ridicularizam e infernizam a vida de outros alunos, levando-os à exclusão, além de danos físicos, morais e materiais. (p.31)

Em geral, podemos notar que as vítimas não dispõem de recursos, status e habilidade para reagir porque estão numa relação desigual de poder com os agressores, ou por razões psicológicas, econômicas ou sociais. Os agressores se valem dessas incapacidades para infligir dano, seja porque alcançaram algum tipo de gratificação emocional com tal postura, ou pretendem obter alguma vantagem específica como se apossar de dinheiro, de objetos da vítima, ou ainda solidificar posições na hierarquia do grupo onde estão inseridos, e aumentar sua popularidade entre os demais colegas. O caráter intencional ainda é justificado pela esco1ha de grupos com características físicas, socioeconômicas, de etnia e orientação sexual, específicas.

Nesse sentido, ser diferente é um pretexto para que o autor do bullying satisfaça a sua necessidade de agredir, ofender e humilhar alguém. Os agressores buscam em suas vítimas algumas diferenças em relação ao grupo no qual estão inseridos. A prática de bullying se constitui numa prática de rejeição perversa, que priva o indivíduo, considerado "diferente e inferior", de sua dignidade, e de seu direito de participar e existir socialmente.

A autora estabelece diferença entre disciplina, indisciplina e bullying: Disciplina são regras básicas de convivência, a indisciplina pode ser percebida como uma fuga as regras, uma não obediência, pelo aluno, às regras preestabelecidas, no caso da escola. (p. 52) Porém, não podem ser confundidas, visto que a primeira provoca transtornos disciplinares de fácil solução. A segunda provoca transtornos mais complicados, pois prejudica o desenvolvimento natural de seus envolvidos, tanto no emocional como no cognitivo e psicológico.

No capítulo quatro, apresenta as consequências e implicações do bullying, tanto para vítima quanto para agressor, demonstra os aspectos psicológicos e cognitivos implicados. Para os agressores, as prováveis consequências podem ser: crença na força 
para solução dos seus problemas; dificuldade em respeitar a lei e os problemas que daí advêm; problemas de relacionamento afetivo social. (p. 62) Já para as vítimas, existe perda de concentração na escola, de autoestima, problemas de relacionamento, síndrome do pânico, depressão, e podem levar a atitudes mais extremas como o suicídio.

No quinto capítulo, discute alguns modelos de prevenção/ intervenção de alguns países para minimizar a violência nas escolas. No entanto, aponta que não existe uma receita única, mas várias que deram certo, como as estratégias estabelecidas no currículo, no projeto pedagógico, articuladas à gestão da escola.

Além disso, considero importante que cada escola estabeleça um projeto que reconheça seus limites, possibilidades, compreendendo ainda sua diversidade. É preciso, pois, que a união, as secretarias estaduais e munícipais se comprometam com a formação de professores para o enfretamento do bullying. O livro, portanto, é uma excelente oportunidade para começar o debate no espaço escolar; um suporte teórico que nos ajudará, entre outras questões, a distinguir os alunos que praticam bullying dos alunos indisciplinados, e medidas de intervenção para sua prevenção. 